\title{
Correction to: The Transition from Hunting-Gathering to Food Production in the Gamo Highlands of Southern Ethiopia
}

\author{
John W. Arthur (D) Matthew C. Curtis • Kathryn J. W. Arthur • Mauro Coltorti • \\ Pierluigi Pieruccini • Joséphine Lesur • Dorian Fuller • Leilani Lucas • \\ Lawrence Conyers • Jay Stock • Sean Stretton • Robert H. Tykot
}

Published online: 2 July 2019

(C) The Author(s) 2019

Correction to: Afr Archaeol Rev (2019) 36:5-65
https://doi.org/10.1007/s10437-018-09322-w

The online version of the original article can be found at https://doi.org/10.1007/s10437-018-09322-w

J. W. Arthur $(\bowtie) \cdot$ K. J. W. Arthur

Department of Society, Culture, and Language, University of

South Florida St. Petersburg, 140 7th Avenue South, St.

Petersburg, FL 33713, USA

e-mail: arthurj@mail.usf.edu

K. J. W. Arthur

e-mail: kjarthur@mail.usf.edu

M. C. Curtis

UCLA Extension, 1145 Gayley Avenue, Los Angeles, CA 90024, USA

e-mail: mccurtis@ucla.edu

\section{Coltorti}

Dipartimento di Scienze della Terra, Universita di Siena, Siena, Italy

e-mail: maurocoltorti@gmail.com

\section{P. Pieruccini}

Dipartimento di Scienze della Terra, Università di Torino, Turin, Italy

e-mail: pieruccinip@gmail.com

J. Lesur

Museum National d'Histoire Naturelle, CNRS, Paris, France e-mail: jolesur@mnhn.fr
The article The Transition from Hunting-Gathering to Food Production in the Gamo Highlands of Southern

D. Fuller

Institute of Archaeology, University College London, London, UK

e-mail: d.fuller@ucl.ac.uk

L. Lucas

Anthropology Program, College of Southern Nevada, Las Vegas, NV, USA

e-mail: lei.m.lucas@gmail.com

\section{Conyers}

Department of Anthropology, University of Denver, Denver, CO, USA

e-mail: lconyers@du.edu

J. Stock

Department of Archaeology, University of Cambridge,

Cambridge, UK

e-mail: jts34@cam.ac.uk

\section{S. Stretton}

Department of Anthropology, University of Illinois at Urbana-Champaign, Champaign, IL, USA

e-mail: scstret@yahoo.com

\section{R. H. Tykot}

Department of Anthropology, University of South Florida, Tampa, FL, USA

e-mail: rtykot@usf.edu 
Ethiopia, written by John W. Arthur, Matthew C. Curtis, Kathryn J. W. Arthur, Mauro Coltorti, Pierluigi Pieruccini, Joséphine Lesur, Dorian Fuller, Leilani Lucas, Lawrence Conyers, Jay Stock, Sean Stretton, and Robert H. Tykot, was originally published electronically on the publisher's internet portal (currently SpringerLink) on 7 March 2019 without open access.

With the author(s)' decision to opt for Open Choice, the copyright of the article changed on June 2019 to (C) The Author(s) 2019 and the article is forthwith distributed under the terms of the Creative Commons Attribution 4.0 International License (http://creativecommons. org/licenses/by/4.0/), which permits use, duplication, adaptation, distribution, and reproduction in any medium or format, as long as you give appropriate credit to the original author(s) and the source, provide a link to the Creative Commons license, and indicate if changes were made.

The original article has been corrected.

Open Access This article is distributed under the terms of the Creative Commons Attribution 4.0 International License (http:// creativecommons.org/licenses/by/4.0/), which permits unrestricted use, distribution, and reproduction in any medium, provided you give appropriate credit to the original author(s) and the source, provide a link to the Creative Commons license, and indicate if changes were made.

Publisher's Note Springer Nature remains neutral with regard to jurisdictional claims in published maps and institutional affiliations. 